\title{
Psychological Well-Being in Teachers During and Post-Covid-19: Positive Psychology Interventions
}

\author{
Diego García-Álvarez ${ }^{1,2 *}$, María José Soler ${ }^{1,3}$ and Lourdes Achard-Braga ${ }^{1,4}$ \\ ${ }^{1}$ Jóvenes Fuertes Uruguay, Montevideo, Uruguay, ${ }^{2}$ Departamento de Ciencias del Comportamiento, Universidad \\ Metropolitana, Caracas, Venezuela, ${ }^{3}$ Centro de Estudios de Psicología, Universidad de Montevideo, Montevideo, Uruguay, \\ ${ }^{4}$ Consejo de Formación en Educación, Administración Nacional de Educación Pública, Montevideo, Uruguay
}

Keywords: psychological well-being, teachers, positive psychology, positive psychology intervention, subjective well-being

\section{INTRODUCTION}

One of the major consequences of Covid-19 in educational settings has been the transition from face-to-face instruction to emergency remote teaching in order to maintain teaching and learning quality standards (United Nations Educational Scientific Cultural Organization, 2020; Garcia et al., 2021). Studies have shown a marked increase in stress and burnout in school teachers (Pellerone, 2021) and technostress among university teachers during the pandemic as a result of different reasons both subjective and objective (Penado-Abilleira et al., 2021), moderate to low levels of stress, anxiety and depression in school and university teachers (Ozamiz-Etxebarria et al., 2021a). Fear of contagion and risk perception in the school context, and teacher with higher levels of anxiety considered that the possibility of reopening schools was not a priority (Weinert et al., 2021). A systematic review carried out on teacher health in times of Covid-19 (Holguín, 2021) has found that physical, mental and social health have been impacted. It is relevant to mention that only two studies were found related to this. One was about interventions for the prevention of physical symptoms (Kayabinar et al., 2020) and the other about emotional competencies (Roman, 2020).

Non-university teachers have reported an increase in psychosocial risks in working environments regarding limited resources, difficulties in organizational justice, interpersonal problems, role confusion and work overload, uncertainty management, psychosomatic disorders, and burnout as well as the responsibility of being the primary learning facilitator of children and teenagers (Prado-Gascó et al., 2020). One of the concerns expressed by teachers has involved assessments, including assessment tools and strategies, monitoring student learning and ethical issues related to students' behaviors (Jelińska and Paradowski, 2021).

In addition to other factors determined by education administrations, vaccination plans in some parts of the world have contributed to the gradual return to face to face instruction or at least a hybrid model of education. Nevertheless, teachers who have faced the prospect of going back to onsite teaching have experienced anxiety about contagion risk as well as falling behind or having difficulty keeping up with the planned teaching schedule and overall student progress (Wakui et al., 2021). Teachers who have returned to face-to face lessons have reported high levels of anxiety, stress, and even depression, all of which were likely exacerbated by the emotional experience they have gone through during the lockdown period, the uncertainty about contagion in schools and managing their workload from home (Ozamiz-Etxebarria et al., 2021b).

Teaching staff are not coming back to what was considered a "normal" school environment before the pandemic breakout (Darling-Hammond and Hyler, 2020; Ellis et al., 2020; Brunzell et al., 2021; Pressley, 2021a). Educational institutions are reopening after high levels of Covid-19 and with a current marked increase in variants such as Delta. In this context, it is worth considering that we may be coming back to school experiencing collective psychosocial trauma (Bergren, 2021; Gonçalvez-Boggio, 2021). A scenario that promotes teacher burnout (Pressley, 2021b). With 
the current educational situation, we must reflect upon how to promote teachers' psychological well-being both in the presentday and post-Covid-19.

In order to identify the research on teachers' psychological well-being in the context of the COVID-19 pandemic, a systematic review was carried out following the PRISMA method (Moher et al., 2009). Following each of the phases, a comprehensive literature search was conducted in three databases: SCOPUS, Web of Science (all collections) and EBSCO (all collections), using the keywords "wellbeing" OR "well being" OR "well-being” AND "teacher" OR "teacher" AND "positive psychology” AND “covid-19” OR “coronavirus" OR "2019ncov” OR "sars-cov-2" OR "cov-19" identified anywhere in the registry. The search for primary sources included only English and Spanish language scientific articles. The initial search yielded four results.

After discarding duplicate works, a total of three studies were identified. The analysis of each of them resulted in: (a) a qualitative research about the trauma approach in conjunction with applied positive psychology for elementary school teachers (Brunzell et al., 2021); (b) a study focused on coping strategies in relation to well-being, stress and negative emotions in language teachers at different teaching levels (MacIntyre et al., 2020); and (c) a theoretical proposal focused on methods and teaching strategies based on well-being and positive psychology for teachers but focused on student well-being (Chu, 2020).

Given the few studies found in the context of the COVID19 pandemic, the intention of this article, which focuses its efforts on the contribution of positive psychology to teachers' well-being, is relevant. For this purpose, a new systematic review was conducted following the steps described above. However, the descriptors associated with COVID-19 were substituted by research oriented to applications or intervention programs ("program" OR "intervention"). In this case, 89 articles were found in the three databases consulted. Twenty-six of these were duplicates.

The titles and abstracts of 63 articles were read. The selection criteria were: (1) research focused on teachers, (2) positive psychology topics, (3) in English or Spanish. The final sample consisted of 12 research studies. We identified $66.7 \%(n=8)$ quantitative paradigm studies, $33.3 \%(n=$ 4) with a qualitative design. Only $16.6 \%(n=2)$ of them were published in Spanish. The findings highlight the fact that, although the rise of positive psychology applied to education has been important in recent years, the work developed has a greater emphasis on the context of student well-being. There is little research that considers the teacher from a person-centered approach, despite being an essential actor for the development of positive education (Rahm and Heise, 2019; White, 2021). Perspectives offered by Positive Psychology provide us with some important answers. Please note that references to "teaching staff" in this article refer to teachers working at different formal educational levels including preschool, primary, secondary, and university or higher education.

\section{POSITIVE PSYCHOLOGY IN TEACHERS' WELL-BEING}

Teachers' well-being is a complex construct, which has been conceptualized as the absence of negative conditions such as teacher's stress, demotivation and even burnout (Huertas and Dávila, 2020; Bastías, 2021). Teachers' well-being has also been studied as it relates to coping strategies and engagement and recovery from work (Pöysä et al., 2021). From the perspective of Positive Psychology, well-being may be analyzed with a holistic approach such as Seligman's PERMA model (Seligman, 2012) as well as in eudaimonic dimensions such as the multidimensional psychological well-being model proposed by Ryff $(1989,2014)$. It is important to understand that well-being is a complex construct that includes a variety of subjective indicators. Some of which are related to personal growth and self-actualization, which must always be considered in context. Research measuring teachers' psychological well-being has yielded interesting results. These may suggest guidelines for the development of psychosocial intervention strategies.

When focusing on psychosocial interventions, the strategies to be developed may better fit into an approach that favors health promotion, and prevention risk factors along with primary prevention of psychopathology. These may be universal interventions targeting all teaching staff. From a theoretical point of view, these interventions aimed at increasing the protective factors for mental health and well-being of teachers (Branand and Nakamura, 2017) are based on the Job Demands-resources Model (Bakker and Demerouti, 2013), the Theory of Flow and Optimal Experience (Csikszentmihalyi, 1988), the Classification of Character Strengths and Virtues (Peterson and Seligman, 2004), the Social Cognitive Career Theory (Lent et al., 1994), and the Self-determination Theory (Ryan and Deci, 2017).

Furthermore, previous research involving teachers at different educational levels has identified factors affecting teachers in the workplace. These should be considered when addressing risk reduction and burnout prevention (Carlotto and Câmara, 2017; Tabares-Díaz et al., 2020). The above mentioned factors include interpersonal variables such as emotional expression and regulation, motivation, self-efficacy, and teacher engagement (García-Renedo et al., 2006; Perandones-Gonzalez et al., 2014; Lozano-Paz and Reyes-Bossio, 2017).

In addition, context-bound variables related to peer support and collaboration, school work environment, school leadership and management, and the impact of public-school policies (Dávila, 2018) should also be considered. In the field of Positive Psychology, specific interventions aimed at promoting multidimensional psychological well-being have been implemented (e.g., multidimensional well-being workshops for teachers, Leal-Soto et al., 2014). Particular character strengths such as gratitude (e.g., counting blessings, Chan, 2010) can decrease symptoms of depression in teachers and increase their level of satisfaction (e.g., counting blessings vs. misfortunes, Chan, 2011, 2013). Mindfulness interventions may be used to strengthen personal resources, thereby reducing work stress among teachers (Taylor et al., 2015). 
In the research laboratory of Jóvenes Fuertes Uruguay, multicomponent interventions aimed at promoting psychological well-being in teachers have been developed. The goals of the Positive Psychology Course Applied to Education (CUPPAE according to its acronym in Spanish) were to increase the psychological well-being of educational staff through the identification of their virtues and character strengths, and to provide training in teaching strategies to apply positive psychology in their classrooms. The study had a pretest-posttest design with teachers of various educational levels.

The intervention consisted of eight modules providing a formative journey through positive psychology, elements of well-being, character strengths, positive education and strategies, mental styles, resilience and optimism, mindfulness in conjunction with self-regulation, emotional management, empathy and compassion. The results indicated a significant increase in psychological well-being in each of its dimensions in the participating teachers before and after the intervention. It was concluded that the intervention presented satisfactory preliminary results (García-Álvarez et al., 2020).

The Jóvenes Fuertes research laboratory has developed an additional multi-component positive psychology intervention aimed at developing multidimensional psychological wellbeing and gratitude. This intervention uses a pre- and postmeasurement methodology with a single group, and comprises eight sessions. In this intervention, teachers start from a Positive Psychology foundation, well-being models, and focus on each of the character strengths including an organized gratitude campaign in the school environment. Pre and post-tests results have indicated a marked increase in teachers' psychological wellbeing and gratitude. It was concluded that the intervention could be used to promote psychological well-being, gratitude and mental health in teachers (García-Álvarez and Soler, 2021).

The results of both studies suggest two significant findings. First, regarding continuous professional development, the main objective of the intervention must be to train teachers to apply positive psychology both in their own lives and to implement its principles in the classroom. Second, regarding the nature of the psychological intervention, the mental health of the teachers and the educational community as a whole must be promoted. The results of these studies provide recommendations indicating that any positive psychology intervention designed for teachers should integrate all aspects, including teaching practice, educational leadership, and school management. Similarly, these interventions should address specific situations related to teacher distress, as indicated by the prevention model in Keyes (2002) two-factor model (Kern et al., 2014; Brunzell et al., 2021; World Health Organization, 2021).

\section{TEACHER WELL-BEING DURING AND AFTER COVID: IDEAS FROM ADVERSITY}

The Covid 19 pandemic will continue to present challenges to the quality of education at many different levels. The following discussion by the authors suggests possible interventions or guidelines to maintain and promote teachers' well-being during a difficult time. According to Waters (2021), actions taken to promote school well-being should be systematized and based on scientific data to gather empirical evidence that will eventually be reported in academic or professional environments.

The authors promote goals to empower teachers through teaching practices that integrate wellness practices into their curricula. Creating interventions with a context-based approach that will foster skills to increase well-being in the classroom (e.g., Waters, 2021). Social relationships and connections are the building blocks of multidimensional well-being models. Relationships between teachers and students are paramount in the development of well-being and these have a special importance during the Covid-19 pandemic. Studies have revealed the relevance of the interaction between teachers and students in an online teaching environment (Alqurshi, 2020; Bao, 2020; Chanchí-Golondrino et al., 2021; Hamdan et al., 2021; Jelińska and Paradowski, 2021).

Consequently, it is important that interventions aimed at promoting teacher well-being include practical strategies to improve interpersonal interactions. These include emotional intelligence, empathy, assertiveness, compassion, etc., which can influence the socioemotional classroom environment and improve relationships between colleagues and teaching peers. Psychological working resources that enhance reflective teaching practices and improve teaching and learning should be promoted. These would include character strengths such as gratitude, creativity, love of learning, bravery, and others (White, 2021). Fostering teacher autonomy in decision making may be achieved with institutional support and a respectful leadership based on mutual trust and adjusted to different working conditions (Naegeli Costa et al., 2021).

The authors identify the importance of promoting flow experiences, which will lead to lasting engagement to teaching experiences as they create lesson plans and classroom materials, deliver lessons and other teaching duties. These flow experiences may prove to be protective factors against stressors, burnout, and teacher drop out (Millán de Lange et al., 2014). The authors stress the essential inclusion of a trauma informed care focus in well-being interventions for teachers during and post-Covid (Brunzell, 2021) as the pandemic may be experienced as a psychosocial trauma by the teachers (Gonçalvez-Boggio, 2021). This trauma-informed care perspective may be useful for teachers to help themselves and to better understand other members of the educational community that may need support in the re-adaptation process.

One of the proposals is the implementation of Professional Development Teacher Communities (Webb et al., 2009; Vaillant, 2019; García-Álvarez, 2020) focused on well-being as a systematic way to expand the knowledge oriented to the continuous development of teachers, both at a personal and professional level to improve the quality of education. In this regard, the role of educational leadership is key to implementing this initiative. In addition to strategic alliances with other specialists inside and outside the school such as psychologists, counselors, etc., it is important to consider the overlap between sectors either inside or outside the educational system. For example, the areas of labor and health (Karaman et al., 2021). 
The benefits of this initiative will be the improvement of pedagogical practices, reconfiguration of professional teaching competencies, increased recognition of teamwork and the organization of work teams. The advice and help of teaching leaders and colleagues will be sought and examples of good educational practices identified. A systematic intervention oriented to medium and long-term outcomes must be framed with quality educational management and with the school as a construction of well-being spaces, a center for promoting mental health (García-Álvarez et al., 2021).

The professional teacher learning community can mobilize the factors that generate organizational learning with a clear management commitment open to continuous learning and a climate that promotes learning. Members of the educational community must be located in an environment that favors training and the exchange of experiences, and must have an infrastructure that allows the educational organization to function optimally in all its aspects. Valid and reliable psychometric scales to assess constructs related to teacher wellbeing should be included in any proposed study (e.g., Renshaw et al., 2015). Through this initiative, teacher empowerment would be promoted by involving teachers in decisions (Yusoff and Tengku-Ariffin, 2020). In conclusion, the authors call for the design of public policies for teacher training, professional development and retention in the education system to face the

\section{REFERENCES}

Alqurshi, A. (2020). Investigating the impact of COVID-19 lockdown on pharmaceutical education in Saudi Arabia-A call for a remote teaching contingency strategy. Saudi Pharm. J. 28, 1075-1083. doi: $10.1016 /$ j.jsps.2020.07.008

Bakker, A. B., and Demerouti, E. (2013). Job demands-resources model. Rev. Psicol. Trabajo Organ. 29, 107-115. doi: 10.5093/tr2013a16

Bao, W. (2020). COVID-19 and online teaching in higher education: a case study of Peking University. Hum. Behav. Emerg. Technol. 2, 113-115. doi: 10.1002/hbe2.191

Bastías, L. (2021). El Bienestar subjetivo y la Calidad de vida: una aproximación desde el ejercicio de la docencia. Educere. 25, 897-908.

Bergren, M. D. (2021). Post-COVID-19: trauma-informed care for the school community. J. School Nurs. 37:145. doi: 10.1177/105984052110 04709

Branand, B., and Nakamura, J. (2017). "The well-being of teachers and professors," in: The Wiley Blackwell Handbook of the Psychology of Positivity and StrengthsBased Approaches at Work, eds. L. Oades, M. Steger, A. Delle Fave, and J. Passmore (Chichester: John Wiley and Sons, Ltd.), 466-490.

Brunzell, T. (2021). "Trauma-aware practice and positive education," in The Palgrave Handbook of Positive Education, eds. M. L. Kern, M. L. Wehmeyer (Cham: Palgrave Macmillan). p. 205-223.

Brunzell, T., Waters, L., and Stokes, H. (2021). Trauma-informed teacher wellbeing: teacher reflections within trauma-informed positive education. Austr. J. Teach. Educ. 46, 1-17. doi: 10.14221/ajte.2021v46n5.6

Carlotto, M. S., and Câmara, S. G. (2017). Psychosocial risks associated with burnout syndrome among university professors. Avances Psicol Latinoam. 35, 447-457. doi: 10.12804/revistas.urosario.edu.co/apl/a.4036

Chan, D. W. (2010). Gratitude, gratitude intervention and subjective well-being among Chinese school teachers in Hong Kong. Educ. Psychol. 30, 139-153. doi: 10.1080/01443410903493934

Chan, D. W. (2011). Burnout and life satisfaction: does gratitude intervention make a difference among Chinese school teachers in Hong Kong? Educ. Psychol. 31, 809-823. doi: 10.1080/01443410.2011.608525 challenges ahead. Challenges that the political and educational actors of the system must assume with leadership.

\section{AUTHOR CONTRIBUTIONS}

DG-Á: formulation of the idea, initial and final writing, and constant revision. MS and LA-B: reviews, contributions, and final writing. All authors have contributed to the work and have approved the final version submitted.

\section{FUNDING}

The authors declare that this study received funding from Jóvenes Fuertes Uruguay. The funder was not involved in the study design, collection, analysis, interpretation of data, and the writing of this article or the decision to submit it for publication.

\section{ACKNOWLEDGMENTS}

The authors would like to express their gratitude to the entire team of Jóvenes Fuertes Uruguay, especially Carina Zerbino and Inés Ruiz. Additionally, the authors wish to thank Professor Rubia Cobo-Rendón (Universidad de Concepción, Chile) for her specific guidance regarding the systematic review, and also the reviewers for their recommendations to improve this article.

Chan, D. W. (2013). Counting blessings versus misfortunes: positive interventions and subjective well-being of Chinese school teachers in Hong Kong. Educ. Psychol. 33, 504-519. doi: 10.1080/01443410.2013.785046

Chanchí-Golondrino, G. E., Ospino-Pinedo, M. E., and García-Bolaños, A. (2021). Emociones y sentimientos en docentes universitarios durante la pandemia del COVID-19. Rev Venezolana Gerencia 26, 123-139. doi: 10.52080/rvgluz.26.e5.9

Chu, T. L. (A). (2020). Applying positive psychology to foster student engagement and classroom community amid the COVID-19 pandemic and beyond. Scholarsh. Teach. Learn. Psychol. doi: 10.1037/stl0000238. [Epub ahead of print].

Csikszentmihalyi, M. (1988). "The future of flow," in Optimal Experience: Psychological Studies of Flow in Consciousness, eds. M. Csikszentmihalyi, and I. S. Csikszentmihalyi (Cambridge: Cambridge University Press), 364-383.

Darling-Hammond, L., and Hyler, M. E. (2020). Preparing educators for the time of COVID... and beyond. Eur. J. Teach. Educ. 43, 457-465. doi: $10.1080 / 02619768.2020 .1816961$

Dávila, J. (2018). “Bienestar profesional del docente en la escuela: revisión teórica y estrategias de intervención desde la psicología educacional," in Procesos y Actores: Claves Para el Asesoramiento Psicoeducativo. Temas de Psicología Educacional. Contribuciones Para la Formación de Especialidad, Vol. 1, ed. F. Leal (Buenos Aires: Noveduc), 297-326.

Ellis, V., Steadman, S., and Mao, Q. (2020). 'Come to a screeching halt': can change in teacher education during the COVID-19 pandemic be seen as innovation? Eur. J. Teach. Educ. 43, 559-572. doi: 10.1080/02619768.2020.1821186

Garcia, R., Paraiso, L. O., Sy-Luna, G., and Laraño, L. (2021). Impact of covid19 pandemic on work-related stress among university faculty: a longitudinal study. Int. J. Recent Adv. Multidiscipl. Res. 8, 6725-6728.

García-Álvarez, D. (2020). Estrategias y recursos para protegerse en la docencia. Almanaque. 10, 56-59.

García-Álvarez, D., Hernández- Lalinde, J., Ureña-Villamizar, Y., SuddyOlarte, P., and Medina-Azuaje, V. (2021). Measurement and comparison of teacher attitude towards mental health in school. Retos 43, 660-671. doi: 10.47197/retos.v43i0.89365

García-Álvarez, D., Soler, M., Achard-Braga, L., and Cobo-Rendón, R. (2020). Program of positive psychology applied to education on the 
psychological wellbeing of educational actors. Rev. Electron. Educ. 24, 1-24. doi: 10.15359/ree.24-1.19

García-Álvarez, D., and Soler, M. J. (2021). Docentes agradecidos y con bienestar: efecto de una intervención psicoeducativa. Inf. Psicol. 21, 201-215. doi: $10.18566 /$ infpsic.v21n1a13

García-Renedo, M., Llorens, S., Cifre, E., and Salanova, M. (2006). Antecedentes afectivos de la auto-eficacia docente: un modelo de relaciones estructurales. Rev. Educ. 339, 387-400.

Gonçalvez-Boggio, L. (2021). Trauma y Pandemia. Efectos Psicosociales $e$ Intervenciones Clínicas. Montevideo: Psicolibros.

Hamdan, K. M., Al-Bashaireh, A. M., Zahran, Z., Al-Daghestani, A., Samira, A. H., and Shaheen, A. M. (2021). University students' interaction, Internet self-efficacy, self-regulation and satisfaction with online education during pandemic crises of COVID-19 (SARS-CoV-2). Int. J. Educ. Manag. 35, 713-725. doi: 10.1108/IJEM-11-2020-0513

Holguín, E. C. (2021). Implicaciones de la pandemia por COVID-19 en la salud docente. Revisión sistemática. Rev. Temas Sociol. 28, 113-142. doi: 10.29344/07196458.28.2794

Huertas, J., and Dávila, J. (2020). Claves contextuales y psicológicas del bienestar docente. Cuad. pedagog. 507, 73-76.

Jelińska, M., and Paradowski, M. B. (2021). Teachers' perception of student coping with emergency remote instruction during the COVID-19 pandemic: the relative impact of educator demographics and professional adaptation and adjustment. Front. Psychol. 12:648443. doi: 10.3389/fpsyg.2021.648443

Karaman, M. A., Eşici, H., Tomar, I. H., and Aliyev, R. (2021). COVID-19: are school counseling services ready? Students' psychological symptoms, school counselors' views, and solutions. Front. Psychol. 12:647740. doi: 10.3389/fpsyg.2021.647740

Kayabinar, E., Kayabinar, B., Önal, B., Zengin, H. Y., and Köse, N. (2020). The musculoskeletal problems and psychosocial status of teachers giving online education during the COVID-19 pandemic and preventive telerehabilitation for musculoskeletal problems. Work 68, 33-43. doi: 10.3233/WOR-203357

Kern, M., Waters, L., Adler, A., and White, M. (2014). Assessing employee wellbeing in schools using a multifaceted approach: associations with physical health, life satisfaction, and professional thriving. Psychology 5, 500-513. doi: $10.4236 /$ psych. 2014.56060

Keyes, C. L. (2002). The mental health continuum: from languishing to flourishing in life. J. Health Soc. Behav. 43, 207-222. doi: 10.2307/3090197

Leal-Soto, F., Dávila, J., and Valdivia, Y. (2014). Bienestar psicológico y prácticas docentes con efectos motivacionales orientadas al aprendizaje. Univ. Psychol. 13, 1037-1046. doi: 10.11144/Javeriana.UPSY13-3.bppd

Lent, R. W., Brown, S. D., and Hackett, G. (1994). Toward a unifying social cognitive theory of career and academic interest, choice, and performance. J. Vocat. Behav. 45, 79-122. doi: 10.1006/jvbe.1994.1027

Lozano-Paz, C. R., and Reyes-Bossio, M. (2017). Docentes universitarios: una mirada desde la Autoeficacia general y engagement laboral. Rev. Digit. Invest. Docencia Univ. 11, 134-148. doi: 10.19083/ridu.11.503

MacIntyre, P. D., Gregersen, T., and Mercer, S. (2020). Language teachers' coping strategies during the Covid-19 conversion to online teaching: correlations with stress, wellbeing and negative emotions. System 94:102352. doi: 10.1016/j.system.2020.102352

Millán de Lange, A. C., García-Álvarez, D., and D’Aubeterre-López, M. E. (2014). Efecto de la inteligencia emocional y flujo en el trabajo sobre estresores y bienestar psicológico: análisis de ruta en docentes. Rev. Colomb. Psicol. 23, 207-228. doi: 10.15446/rcp.v23n1.37676

Moher, D., Liberati, A., Tetzlaff, J., Altman, D. G., and Prisma Group. (2009). Reprint-preferred reporting items for systematic reviews and meta-analyses: the PRISMA statement. Phys. Therapy 89, 873-880. doi: 10.1093/ptj/89.9.873

Naegeli Costa, C., Park, N., and Kira, M. (2021). \#ArmMeWith: lesources for teacher wellbeing. Int. J. Wellbeing 11, 20-37. doi: 10.5502/ijw.v11i2.1365

Ozamiz-Etxebarria, N., Berasategi Santxo, N., Idoiaga Mondragon, N., and Dosil Santamaría, M. (2021b). The psychological state of teachers during the COVID19 crisis: the challenge of returning to face-to-face teaching. Front. Psychol. 11:620718. doi: 10.3389/fpsyg.2020.620718

Ozamiz-Etxebarria, N., Dosil Santamaría, M., Idoiaga Mondragon, N., and Berasategi Santxo, N. (2021a). Estado emocional del profesorado de colegios y universidades en el norte de España ante la COVID-19. Rev. Español. Salud Públ. 95, e1-e8. Available online at: https://www.mscbs.gob.es/biblioPublic/
publicaciones/recursos_propios/resp/revista_cdrom/VOL95/O_BREVES/ RS95C_202102030.pdf

Pellerone, M. (2021). Self-perceived instructional competence, self-efficacy and burnout during the covid-19 pandemic: a study of a group of Italian school teachers. Eur. J. Invest. Health Psychol. Educ. 11, 496-512. doi: 10.3390/ejihpe11020035

Penado-Abilleira, M., Rodicio-García, M. L., Ríos-de Deus, M. P., and Mosquera-González, M. J. (2021). Technostress in Spanish University teachers during the COVID-19 pandemic. Front. Psychol. 12:617650. doi: $10.3389 /$ fpsyg.2021.617650

Perandones-Gonzalez, T. M. P., Torres, L. H., and Carreres, A. L. (2014). Fortalezas y virtudes personales del profesorado y su relación con la eficacia docente. Int. J. Dev. Educ. Psychol. 7, 141-150. doi: 10.17060/ijodaep.2014.n1.v7.785

Peterson, C., and Seligman, M. E. (2004). Character Strengths and Virtues: A Handbook and Classification, Vol. 1. New York, NY: Oxford University Press.

Pöysä, S., Pakarinen, E., and Lerkkanen, M.-K. (2021). Patterns of teachers' occupational well-being during the COVID-19 pandemic: relations to experiences of exhaustion, recovery, and interactional styles of teaching. Front. Educ. 6:699785. doi: 10.3389/feduc.2021.699785

Prado-Gascó, V., Gómez-Domínguez, M. T., Soto-Rubio, A., Díaz-Rodríguez, L., and Navarro-Mateu, D. (2020). Stay at home and teach: a comparative study of psychosocial risks between spain and mexico during the pandemic. Front. Psychol. 11:566900. doi: 10.3389/fpsyg.2020.566900

Pressley, T. (2021a). Returning to teaching during COVID-19: an empirical study on elementary teachers' self-efficacy. Psychol. Schs. 58, 1611-1623. doi: $10.1002 /$ pits. 22528

Pressley, T. (2021b). Factors contributing to teacher burnout during COVID-19. Educ. Res. 50, 325-327. doi: 10.3102/0013189X211004138

Rahm, T., and Heise, E. (2019). Teaching happiness to teachers - development and evaluation of a training in subjective well-being. Front. Psychol. 10:2703. doi: 10.3389/fpsyg.2019.02703

Renshaw, T. L., Long, A. C. J., and Cook, C. R. (2015). Assessing teachers' positive psychological functioning at work: development and validation of the teacher subjective wellbeing questionnaire. School Psychol. Q. 30, 289-306. doi: $10.1037 / \mathrm{spq} 0000112$

Roman, T. A. (2020). Supporting the mental health of teachers in COVID19 through trauma-informed educational practices and adaptive formative assessment tools. J. Technol. Teach. Educ. 28, 473-481. Available online at: https://www.learntechlib.org/primary/p/216363/

Ryan, R. M., and Deci, E. L. (2017). Self-Determination Theory: Basic Psychological Needs in Motivation, Development, and Wellness. New York, NY: The Guilford Press.

Ryff, C. D. (1989). Happiness is everything, or is it? Explorations on the meaning of psychological well-being. J. Pers. Soc. Psychol. 57, 1069-81. doi: 10.1037/0022-3514.57.6.1069

Ryff, C. D. (2014). Psychological well-being revisited: advances in the science and practice of eudaimonia. Psychother. Psychosom. 83, 10-28. doi: $10.1159 / 000353263$

Seligman, M. E. (2012). Flourish: A Visionary New Understanding of Happiness and Well-Being. New York, NY: Simon and Schuster.

Tabares-Díaz, Y. A., Martínez-Daza, V. A., and Matabanchoy-Tulcán, S. M. (2020). Síndrome de Burnout en docentes de Latinoamérica: una revisión sistemática. Univ. Salud 22, 265-279. doi: 10.22267/rus.202203.199

Taylor, C., Harrison, J., Haimovitz, K., Oberle, E., Thomson, K., SchonertReichl, K., et al. (2015). Examining ways that a mindfulness-based intervention reduces stress in public school teachers: a mixedmethods study. Mindfulness 7, 115-129. doi: 10.1007/s12671-0150425-4

United Nations Educational Scientific and Cultural Organization (2020). COVID-19 Impact on Education Data. COVID-19 Education Disruption and Response. Paris: The United Nations Educational, Scientific and Cultural Organization, UNESCO.

Vaillant, D. (2019). Directors and teacher learning communities: a field under construction. Rev. Eletrôn. Educ. 13, 87-106. doi: 10.14244/198271993073

Wakui, N., Abe, S., Shirozu, S., Yamamoto, Y., Yamamura, M., Abe, Y., et al. (2021). Causes of anxiety among teachers giving face-to-face lessons after the reopening of schools during the COVID-19 pandemic: a cross-sectional study. BMC Public Health 21:1050. doi: 10.1186/s12889-021-11130-y 
Waters, L. (2021). "Positive education pedagogy: shifting teacher mindsets, practice, and language to make wellbeing visible in classrooms," in The Palgrave Handbook of Positive Education, eds. M. L. Kern, and M.L. Wehmeyer (Cham: Palgrave Macmillan). p. 137-164

Webb, R., Vulliamy, G., Sarja, A., Hämäläinen, S., and Poikonen, P. L. (2009). Professional learning communities and teacher well-being? A comparative analysis of primary schools in England and Finland. Oxford Rev. Educ. 35, 405-422. doi: 10.1080/03054980902935008

Weinert, S., Thronicke, A., Hinse, M., Schad, F., and Matthes, H. (2021). School teachers' self-reported fear and risk perception during the COVID-19 pandemic - a nationwide survey in Germany. Int. J. Environ. Res. 18:9218. doi: 10.3390/ijerph181 79218

White, M. A. (2021). "Positive Professional practice: a strength-based reflective practice teaching model," in The Palgrave Handbook of Positive Education, eds. M. L. Kern, M.L. Wehmeyer (Cham: Palgrave Macmillan). p. 165-204.

World Health Organization (2021). WHO Menu of Cost-Effective Interventions for Mental Health. Geneva: World Health Organization.

Yusoff, S. M., and Tengku-Ariffin, T. F. (2020). Looking after teacher wellbeing: does teacher empowerment matter? Malays.
Online J. Educ. Manag. 8, 43-56. doi: 10.22452/mojem.vol 8no4.3

Conflict of Interest: The authors declare that the research was conducted in the absence of any commercial or financial relationships that could be construed as a potential conflict of interest.

Publisher's Note: All claims expressed in this article are solely those of the authors and do not necessarily represent those of their affiliated organizations, or those of the publisher, the editors and the reviewers. Any product that may be evaluated in this article, or claim that may be made by its manufacturer, is not guaranteed or endorsed by the publisher.

Copyright (C) 2021 García-Álvarez, Soler and Achard-Braga. This is an open-access article distributed under the terms of the Creative Commons Attribution License (CC $B Y)$. The use, distribution or reproduction in other forums is permitted, provided the original author(s) and the copyright owner(s) are credited and that the original publication in this journal is cited, in accordance with accepted academic practice. No use, distribution or reproduction is permitted which does not comply with these terms. 